
ISSN : 2615-1995, E-ISSN : 2615-0654

J. Madani., Vol. 2, No. 2, September 2019 (324 - 330)

(C)2018 Lembaga Kajian Demokrasi

MADANI

dan Pemberdayaan Masyarakat (LKD-PM)

\title{
Analisis Pengaruh Disiplin Kerja dan Motivasi Terhadap Kinerja Karyawan Pada Departemen Sales Marketing PT Perma Plasindo Jakarta
}

\author{
Ratna Sari \\ Fakultas Ekonomi, Universitas Pamulang \\ ratnasariasemm@gmail.com
}

\begin{abstract}
Abstrak
Tujuan penelitian ini untuk mengetahui pengaruh antara disiplin kerja terhadap kinerja karyawan pada departemen sales marketing PT Perma Plasindo Jakarta; pengaruh antara motivasi kerja terhadap kinerja karyawan pada departemen sales marketing PT Perma Plasindo Jakarta; pengaruh secara parsial maupun simultan antara disiplin kerja dan motivasi terhadap kinerja karyawan pada departemen sales marketing PT Perma Plasindo Jakarta. Metode Penelitian ini adalah deskriptif dan kuantatif dan jenis peneltian asosiatif. Teknik sampling yang digunakan sampling jenuh/sensus dengan sampel sebanyak 84 responden. Analisis menggunakan analisis regresi linear berganda. Hasil penelitian ini dapat disimpulkan bahwa, secara parsial menyatakan terdapat pengaruh antara disiplin kerja terhadap kinerja karyawan dengan nilai Sig $0.002<0,05$ atau nilai $t_{\text {hitung }} 3,132>t_{\text {tabel }}$ 1,989. Pengaruh motivasi kerja terhadap kinerja karyawan menunjukkan bahwa, secara parsial terdapat pengaruh motivasi kerja terhadap kinerja karyawan dengan nilai Sig $0.000<0,05$ atau nilai $t_{\text {hitung }} 4,459>t_{\text {tabel }} 1,989$. Pengaruh secara simultan antara disiplin kerja dan motivasi kerja terhadap kinerja karyawan Departemen Sales Marketing Pada PT Perma Plasindo Jakarta, hal ini ditunjukkan dengan nilai $F_{\text {hitung }} 23,670>F_{\text {tabel }} 3.11$ atau nilai Sig 0,000 $<0.05$.
\end{abstract}

Kata Kunci: Disiplin Kerja, Motivasi Kerja, Kinerja

\begin{abstract}
The purpose of this study is to determine the effect of work discipline on the performance of employees in the sales marketing department of PT Perma Plasindo Jakarta; the influence between work motivation on the performance of employees in the sales marketing department of PT Perma Plasindo Jakarta; the influence partially or simultaneously between work discipline and motivation on the performance of employees in the sales marketing department of PT Perma Plasindo Jakarta. This research method is descriptive and quantative and associative research types. The sampling technique used was saturated sampling / census with a sample of 84 respondents. The analysis uses multiple linear regression analysis. The results of this study can be concluded that, partially states there is an influence between work discipline on the performance of employees with Sig $0.002<0.05$ or $t_{\text {count }}$ value $3.132>t_{\text {table }} 1.989$. The effect of work motivation on employee performance shows that, partially there is an effect of work motivation on employee performance with Sig $0,000<0.05$ or $t_{\text {count }}$ value of 4.459> $t_{\text {table }}$ 1.989. Simultaneous influence between work discipline and work motivation on employee performance in the Sales Marketing Department At PT Perma Plasindo Jakarta, this is indicated by the value of $F_{\text {count }} 23,670>F_{\text {table }} 3.11$ or Sig $0,000<0.05$.
\end{abstract}

Keywords: Work Discipline, Work Motivation, Performance 


\section{PENDAHULUAN}

\section{Latar Belakang}

Kinerja merupakan hasil pencapaian karyawan dalam melaksanakan tugas dan tanggung jawabnya. Banyak faktor yang mempengaruhi kinerja karyawan, salah satunya adalah faktor internal dan eksternal. Kedua faktor tersebut merupakan atribusi yang mempengaruhi kinerja seseorang. Atribusi yang dibuat oleh para pegawai memiliki sejumlah akibat psikologis dan berdasarkan kepada tindakan, seperti kedisiplinan dan bahkan hasil kerja yang berikan.

PT Perma Plasindo adalah anak perusahaan dari PT Batara Indah Indonesia. PT perma Plasindo sebagai anak perusahaan bergerak di bidang usaha untuk memasarkan semua jenis produkproduk BANTEX dari PT Batara Indah Indonesia

Berdasarkan pengamatan penulis, masih ditemukannya permasalahan kinerja karyawan. Salah satu hasil kerja karyawan departemen sales marketing yang menunjukkan pendapatan perusahaaan dari segi penjualan terlihat fluktuatif, berikut peneliti sajikan data penjualan seperti pada tabel di bawah ini.

Jumlah penjualan dari 22 toko Intermedia selama tahun 2014 dan 2015 seperti tabel dibawah ini:

\begin{tabular}{|c|c|c|c|}
\hline \multirow{2}{*}{ No } & \multirow{2}{*}{ Nama Toko Bantex } & \multicolumn{2}{|c|}{ Jumlah Penjualan } \\
\hline & & 2014 & 2015 \\
\hline 1 & Intermedia Bintaro & Rp373,326,058 & Rp313,983,155 \\
\hline 2 & Intermedia Galaxy & Rp168,502,307 & Rp152,916,490 \\
\hline 3 & $\begin{array}{l}\text { Intermedia Harapan } \\
\text { Baru }\end{array}$ & Rp68,699,128 & Rp65,486,874 \\
\hline 4 & $\begin{array}{l}\text { Intermedia Harapan } \\
\text { Indah }\end{array}$ & Rp189,899,250 & Rp179,755,989 \\
\hline 5 & $\begin{array}{l}\text { Intermedia Jababeka } \\
\text { Cikarang }\end{array}$ & Rp235,290,610 & Rp192,161,604 \\
\hline 6 & Intermedia Wisma Asri & Rp179,271,480 & Rp148,745,772 \\
\hline 7 & Intermedia Pahlawan & Rp57,530,821 & Rp67,273,788 \\
\hline 8 & Intermedia Libersa & Rp26,146,308 & Rp25,827,267 \\
\hline 9 & $\begin{array}{l}\text { Intermedia Lippo } \\
\text { Cikarang }\end{array}$ & Rp69,832,427 & Rp70,283,560 \\
\hline 10 & Intermedia Galaxy & Rp123,587,858 & Rp120,608,601 \\
\hline 11 & intermedia bintara & Rp75,961,840 & Rp88,105,773 \\
\hline 12 & Intermedia Cengkareng & Rp171,521,907 & Rp176,095,369 \\
\hline 13 & $\begin{array}{l}\text { Intermedia Kelapa } \\
\text { Gading }\end{array}$ & Rp154,216,164 & Rp129,833,472 \\
\hline 14 & $\begin{array}{l}\text { Intermedia Kemang } \\
\text { Pratama }\end{array}$ & Rp273,573,649 & Rp255,933,460 \\
\hline
\end{tabular}

\begin{tabular}{|r|l|r|r|}
\hline 15 & $\begin{array}{l}\text { Intermedia Rawa } \\
\text { Lumbu }\end{array}$ & Rp275,432,821 & Rp239,852,824 \\
\hline 16 & Intermedia Raden Saleh & Rp85,775,274 & Rp87,374,217 \\
\hline 17 & $\begin{array}{l}\text { Intermedia Villa Nusa } \\
\text { Indah }\end{array}$ & Rp130,497,754 & Rp127,617,998 \\
\hline 18 & Intermedia SUMIR & Rp115,665,957 & Rp99,625,288 \\
\hline 19 & Intermedia Depok & Rp285,955,244 & Rp290,029,241 \\
\hline 20 & Intermedia Torina & $\mathrm{Rp} 33,436,813$ & $\mathrm{Rp} 47,104,891$ \\
\hline 21 & Intermedia Cengkareng & $\mathrm{Rp} 136,195,780$ & $\mathrm{Rp} 124,780,320$ \\
\hline 22 & Intermedia Pondok Kopi & $\mathrm{Rp} 124,066,083$ & $\mathrm{Rp} 100,477,415$ \\
\hline & Total & $\mathrm{Rp} 3,354,385,532$ & $\mathrm{Rp} 3,103,873,368$ \\
\hline
\end{tabular}

Jumlah penjualan dari 18 toko Papper Clip selama tahun 2015 dan 2016 seperti tabel di bawah ini:

\begin{tabular}{|c|c|c|c|}
\hline \multicolumn{4}{|c|}{ Tabel 2. Hasil Penjualan Departemen Sales Toko Papper Clip } \\
\hline \multirow{2}{*}{ No } & \multirow{2}{*}{ Nama Toko Bantex } & \multicolumn{2}{|c|}{ Jumlah Penjualan } \\
\hline & & 2014 & 2015 \\
\hline 1 & $\begin{array}{l}\text { Paper Clip Cibubur } \\
\text { Junction }\end{array}$ & Rp74,190,789 & Rp140,359,203 \\
\hline 2 & $\begin{array}{l}\text { Paper Clip Citywalk } \\
\text { Cikarang }\end{array}$ & Rp86,374,384 & Rp110,853,930 \\
\hline 3 & Paper Clip FX Sudirman & Rp76,353,933 & Rp37,319,604 \\
\hline 4 & Paper Clip Gajah Mada & Rp59,604,744 & Rp73,424,887 \\
\hline 5 & Paper Clip Mid Plaza 2 & Rp54,973,934 & Rp84,766,879 \\
\hline 6 & $\begin{array}{l}\text { Paper Clip Pondok } \\
\text { Indah Mall } 2\end{array}$ & Rp78,363,257 & Rp2,342,506 \\
\hline 7 & Paper Clip Citra Gran & Rp94,377,646 & Rp111,474,121 \\
\hline 8 & $\begin{array}{l}\text { Paper Clip Central Point } \\
\text { Medan }\end{array}$ & Rp204,079,428 & Rp182,057,986 \\
\hline 9 & $\begin{array}{l}\text { Paper Clip Ciputra } \\
\text { Seraya Pekan Baru }\end{array}$ & Rp100,570,296 & Rp105,355,835 \\
\hline 10 & $\begin{array}{l}\text { Paper Clip Sun Plaza } \\
\text { Medan }\end{array}$ & Rp94,482,004 & Rp135,865,589 \\
\hline 11 & $\begin{array}{l}\text { Paper Clip Cinere } \\
\text { Bellevue Mall }\end{array}$ & Rp78,308,631 & Rp102,264,178 \\
\hline 12 & Paper Clip Fatmawati & Rp62,481,233 & Rp83,970,921 \\
\hline 13 & $\begin{array}{l}\text { Paper Clip Gandaria } \\
\text { City }\end{array}$ & Rp243,493,135 & Rp297,348.108 \\
\hline 14 & $\begin{array}{l}\text { Paper Clip Grand } \\
\text { Galaxy Park }\end{array}$ & Rp81,142,635 & Rp159,344,452 \\
\hline 15 & Paper Clip Casablanka & $\operatorname{Rp} 557,664,507$ & Rp650,831,133 \\
\hline 16 & $\begin{array}{l}\text { Paper Clip Mall Kelapa } \\
\text { Gading } 5\end{array}$ & Rp418,590,042 & Rp435,627,531 \\
\hline 17 & $\begin{array}{l}\text { Paper Clip Sumarecon } \\
\text { Mall Bekasi }\end{array}$ & Rp102,798,169 & Rp168,673,107 \\
\hline 18 & $\begin{array}{l}\text { Paper Clip Sumarecon } \\
\text { Mall Serpong }\end{array}$ & Rp193,017,744 & Rp280,147,548 \\
\hline \multicolumn{2}{|r|}{ Total } & $\mathrm{Rp} 2,660,866,511$ & Rp3,162,028,219 \\
\hline \multicolumn{4}{|c|}{ Sumber : Departemen Sales Marketing PT Perma Plasindo 2017} \\
\hline
\end{tabular}

Dari tabel tersebut, jumlah penjualan toko Intermedia setiap tahunnya, mayoritas toko mengalami turun-naik (fluktuatif) jumlah penjualan dari total penjualan selama tahun 2014 dan 2015. Dari tabel tersebut toko yang me- 
ngalami penjualan terbesar selama tahun 2014 adalah toko Intermedia Bintaro dengan jumlah penjualan Rp373,326,058 dan yang terendah selama tahun 2014 terdapat pada Intermedia Torina dengan jumlah penjualan $\mathrm{Rp} 33,436,813$. penjualan terbesar selama tahun 2015 adalah toko Intermedia Bintaro dengan jumlah penjualan Rp313,983,155 dan yang tererendah selama tahun 2015 terdapat pada Intermedia Torina dengan jumlah penjualan Rp47,104,891.

Dari tabel tersebut, jumlah penjualan toko Papper Clip setiap tahunnya, mayoritas toko mengalami turun-naik (fluktuatif) jumlah penjualan dari total penjualan selama tahun 2015 dan 2016. Dari tabel tersebut toko yang mengalami penjualan terbesar selama tahun 2015 adalah toko Paperclip Casablanca dengan jumlah penjualan Rp557,664,507 dan yang terendah selama tahun 2015 terdapat pada Paperclip Mid Plaza 2 dengan jumlah penjualan Rp54,973,934 penjualan terbesar selama tahun 2016 adalah toko Paperclip Casablanca dengan jumlah penjualan Rp650,831,133 dan yang terendah selama tahun 2016 terdapat pada Paperclip Pondok Indah Mall 2 dengan jumlah penjualan Rp2,342,506.

Dalam upaya pencapaian tujuan perusahaan, motivasi menjadi peranan yang sangat penting karena merupakan suatu upaya para manajer untukmendorong, menggugah, dan menimbulkan semangat kerja yang lebih baik bagi karyawannya.

Dari pengamatan peneliti yang peneliti lakukan, saat ini terdapat ketidakpuasan dan kekecewaan karyawan, ketidakpuasan dan kekecewaan karyawan tersebut ditunjukkan pada tingkat ketidakhadiran dan keterlambatan karyawan selama ini yang relatif tinggi, penyelesaian pekerjaan yang tidak tepat waktu sehingga membutuhkan waktu tambahan jam kerja, serta target pencapaian penjualan produk perusahaan yang masih fluktuatif setiap bulannya, sehingga pemberian insentif bagi karyawan tidak merata.

Berikut data absensi yang peneliti dapatkan dari departemen sales yang berjumlah 84 karyawan dapat jumlah ketidakhadiran dan keterlambatan karyawan yang tidak sesuai harapan perusahaan.

\begin{tabular}{|c|c|c|c|c|c|}
\hline \multicolumn{6}{|c|}{ Tabel 3. Absensi Karyawan } \\
\hline \multirow{2}{*}{ Bulan } & \multirow{2}{*}{$\begin{array}{c}\text { Jumlah } \\
\text { Karyawan }\end{array}$} & \multicolumn{2}{|c|}{ Ketidakhadiran } & \multicolumn{2}{|c|}{ Keterlambatan } \\
\hline & & Karyawan & $\%$ & Karyawan & $\%$ \\
\hline Jan-16 & 85 & 4 & $5 \%$ & 12 & $14 \%$ \\
\hline Feb-16 & 85 & 5 & $6 \%$ & 8 & $9 \%$ \\
\hline Mar-16 & 87 & 4 & $5 \%$ & 10 & $11 \%$ \\
\hline Apr-16 & 87 & 5 & $6 \%$ & 11 & $13 \%$ \\
\hline May-16 & 87 & 5 & $6 \%$ & 6 & $7 \%$ \\
\hline Jun-16 & 87 & 4 & $5 \%$ & 8 & $9 \%$ \\
\hline Jul-16 & 89 & 5 & $6 \%$ & 15 & $17 \%$ \\
\hline Aug-16 & 88 & 6 & $7 \%$ & 7 & $8 \%$ \\
\hline Sep-16 & 87 & 7 & $8 \%$ & 8 & $9 \%$ \\
\hline Oct-16 & 87 & 5 & $6 \%$ & 11 & $13 \%$ \\
\hline Nov-16 & 86 & 3 & $3 \%$ & 6 & $7 \%$ \\
\hline Dec-16 & 85 & 3 & $4 \%$ & 12 & $14 \%$ \\
\hline Jan-17 & 85 & 2 & $2 \%$ & 4 & $5 \%$ \\
\hline Feb-17 & 85 & 3 & $4 \%$ & 8 & $9 \%$ \\
\hline Mar-17 & 84 & 2 & $2 \%$ & 12 & $14 \%$ \\
\hline Apr-17 & 84 & 3 & $4 \%$ & 12 & $14 \%$ \\
\hline May-17 & 84 & 4 & $5 \%$ & 10 & $12 \%$ \\
\hline Jun-17 & 84 & 5 & $6 \%$ & 15 & $18 \%$ \\
\hline & & & & r: PT. Perma P & do 2017 \\
\hline
\end{tabular}

Dari tabel tersebut menunjukkan bahwa dari bulan Januari 2016-Juni 2017 tidak ada kehadiran dan ketepatan waktu yang mencapai 100\%. Kurang disiplinnya karyawan dalam kehadiran kerja ini dapat mengakibatkan kerugian bagi karyawan lainnya, di mana karyawan yang hadir menggantikan posisi karyawan yang hadir, sehingga volume pekerjaan dan waktu penyelesaian pekerjaan menjadi bertambah. Hal menimbulkan kekhawatiran bagi perusahaan dalam pencapaian target penjualan serta tujuan perusahaan yang akan mengakibatkan kerugian bagi perusahaan dan karyawan

Selain itu dari pengamatan yang penulis dapatkan dari segi tunjangan yang diberikan, masih terdapat kekurangan, berikut di bawah ini tabel sarana motivasi berupa pemberian kompensasi yang diberikan PT Perma Plasindo kepada karyawannya.

\begin{tabular}{l|c|c|c|c|}
\hline \multicolumn{5}{c}{ Tabel 4. Sarana Motivasi PT Perma Plasindo } \\
\hline \multirow{2}{*}{ Jenis Kompensasi } & 2014 & 2015 & 2016 & 2017 \\
\cline { 2 - 5 } & Tidak Ada & Tidak Ada & BPJS & BPJS \\
\hline $\begin{array}{l}\text { Asuransi } \\
\text { Kesehatan }\end{array}$ & Tidak Ada & Tidak Ada & Tidak Ada & Tidak Ada \\
\hline $\begin{array}{l}\text { Asuransi } \\
\text { Kecelakaan }\end{array}$ & &
\end{tabular}




\begin{tabular}{|l|l|l|l|l|}
\hline Uang Bensin & $\begin{array}{l}\text { Rp15000/ } \\
\text { hari } \\
\text { (Khusus } \\
\text { Sales MD) }\end{array}$ & $\begin{array}{l}\text { Rp15000/ } \\
\text { hari } \\
\text { (Khusus } \\
\text { Sales MD) }\end{array}$ & $\begin{array}{l}\text { Rp15000/ } \\
\text { hari } \\
\text { (Khusus } \\
\text { Sales MD) }\end{array}$ & $\begin{array}{l}\text { Rp15000/ } \\
\text { hari } \\
\text { (Khusus } \\
\text { Sales MD) }\end{array}$ \\
\hline Uang Makan & Tidak Ada & Tidak Ada & Tidak Ada & Tidak Ada \\
\hline $\begin{array}{l}\text { Pensiun / } \\
\text { Pesangon }\end{array}$ & $\begin{array}{l}\text { Kebijakan } \\
\text { Perusahaan }\end{array}$ & $\begin{array}{l}\text { Kebijakan } \\
\text { Perusahaan }\end{array}$ & $\begin{array}{l}\text { Kebijakan } \\
\text { Perusahaan }\end{array}$ & $\begin{array}{l}\text { Kebijakan } \\
\text { Perusahaan }\end{array}$ \\
\hline \multicolumn{5}{|c|}{ Sumber: PT. Perma Plasindo 2017 } \\
\hline
\end{tabular}

Dari tabel di atas menunjukkan bahwa, sarana motivasi yang diberikan perusahaan berupa pemberian kompensasi dengan jenis asuransi kesehatan pada tahun 2014 sampai dengan 2015 kepada karyawannya tidak ada, namun semenjak tahun 2016 sampai sekarang perusahaan memberikan asuransi karyawan dengan menunjuk BPJS untuk pemberian layanan kesehatan. Dari segi uang makan perusahaan tidak memberikan, dan pergantian uang bensin atau transport hanya diperuntukan bagi karyawan dengan Sales Merchendise per karyawan, perusahaan memberikan besaran uang tunai yang dibayar akhir pekan sebesar Rp15000 dengan menunjukkan bukti bon print out dari SPBU.

Pengertian motivasi itu sendiri tidak lepas dari dua kata yaitu "needs" atau kebutuhan dan "want" atau keinginan. Hal ini menyulitkan manajer untuk memberikan alat motivasi yang tepat bagi setiap individu bawahannya. Menurut sebuah teori yang dikemukakan oleh Siagian (2012:11), dalam upaya untuk mencapai tujuan perusahaan, motivasi mempunyai peran yang penting karena merupakan suatu upaya dari para manajer untuk mendorong, menggugah, dan menimbulkan semangat kerja yang lebih baik bagi karyawannya.

\section{Kajian Pustaka}

\section{Disiplin Kerja}

Disiplin kerja merupakan salah satu faktor yang sangat berpengaruh dalam sumber daya manusia. Menurut Hasibuan (2013:23) disiplin kerja merupakan fungsi Manajemen Sumber Daya Manusia yang berkepentingan dan kunci terwujudnya tujuan karena tanpa disiplin yang baik sulit terwujud tujuan yang maksimal.

Kerelaan seseorang dalam menaati semua peraturan perusahaan dan norma sosial yang berlaku dan kesadaran yang menjadi sikap seseorang yang secara sukarela mentaati semua peraturan dan sadar akan tugas serta tanggung jawabnya. Kesediaan merupakan sikap, tingkah laku dan perbuatan seseorang yang sesuai dengan peraturan perusahaan, baik yang tertulis maupun tidak".

\section{Motivasi}

Dalam pencapaian tujuan perusahaan Pengertian motivasi itu sendiri tidak lepas dari dua kata yaitu "needs" atau kebutuhan dan "want" atau keinginan. Menurut Hasibuan (2013:144) perbedaan definisi keinginan (want) dan kebutuhan (needs) adalah keinginan (want) dari setiap orang berbeda, karena dipegaruhi oleh selera, latar belakang dan lingkungannya, sedangkan kebutuhan (needs) semua orang adalah sama. Misalnya semua orang butuh makan (needs), tetapi jenis makanan yang diinginkannya (want) tidak selalu sama tergantung pada selera masingmasing individu. Hal inilah yang menyulitkan manajer untuk memberikan alat motivasi yang tepat bagi setiap individu bawahannya.

Menurut Hasibuan (2013:143) mengemukakan bahwa "Motivasi adalah pemberian daya gerak yang menciptakan kegairahan kerja seseorang agar mereka mau bekerja sama, bekerja efektif, dan terintegrasi dengan segal daya upayanya untuk mencapai kepuasan".

\section{Kinerja}

Kinerja karyawan adalah hasil sinergi dari sejumlah faktor dan banyak faktor yang mempengaruhi kinerja karyawan, menurut Mangkunegara (2013:16) faktor yang mempengaruhi pencapaian kinerja terbagi menjadi dua bagian yaitu Faktor Kemampuan dan Faktor Motivasi.

Menurut Wirawan (2012:5) "kinerja adalah keluaran yang dihasilkan oleh fungsi-fungsi atau indikator-indikator suatu pekerjaan atau suatu profesi dalam waktu tertentu".

\section{METODE}

\section{Metode Penelitian}

Metode penelitian yang dilakukan oleh peneliti bersifat deskriptif kuantitatif. menurut Siregar (2014:15) penelitian deskriptif adalah 
penelitian yang di lakukan untuk mengetahui nilai variabel mandiri, baik satu variabel atau lebih (independent) tanpa membuat perbandingan atau penghubungan dengan variabel lain.

\section{Populasi dan Sampel}

Menurut Siregar (2014:56) populasi penelitian merupakan keseluruhan dari obyek penelitian yang dapat berupa manusia, hewan, tumbuhan, udara, gejala, nilai, peristiwa, sikap hidup dan sebagainya. Populasi dalam penelitian ini adalah 84 karyawan Departemen Sales Marketing Pada PT Perma Plasindo Jakarta.

Sampel adalah prosedur pengambilan data sebagian populasi dan dipergunakan untuk menentukan sifat serta ciri yang dikehendaki dari suatu populasi. (Siregar, 2014:56).

Melihat jumlah populasi yang hanya berjumlah 84 karyawan, maka penulis menggunakan teknik sampling jenuh. Seperti yang dikemukakan oleh Sugiyono (2010:122) sampling jenuh adalah teknik penentuan sampel bila semua anggota populasi digunakan sebagai sampel. Dengan demikian sampel yang penulis gunakan sama dengan jumlah populasi yang berjumlah 84 responden.

\section{Rancangan Analisis}

Teknik analisa data dalam penelitian ini menggunakan statistik, langkah-langkah dalam pengujian statistik dalam penelitian ini adalah analisis regresi berganda. Menurut Sugiyono (2010:277), analisis regresi berganda, yaitu analisis yang digunakan peneliti, bila bermaksud meramalkan bagaimana keadaan (naik turunnya) variabel dependen (kriterium), bila dua atau lebih variabel independen sebagai faktor prediktor dimanipulasi (di naik turunkan nilainya). Persamaan regresi untuk tiga prediktor adalah $: \mathrm{Y}=\mathrm{a}+$ $\mathrm{b}_{1} \mathrm{X}_{1}+\mathrm{b}_{2} \mathrm{X}_{2}+\mathrm{e}$.

\section{HASIL dan PEMBAHASAN Hasil}

Hasil uji Regresi lianear berganda menggunakan bantuan SPSS adalah sebagai berikut:

\begin{tabular}{|c|c|c|c|c|c|}
\hline \multirow{2}{*}{\multicolumn{6}{|c|}{$\begin{array}{l}\text { Tabel 5. Hasil Uji Regresi Li } \\
\text { Coefficients }^{\mathrm{a}}\end{array}$}} \\
\hline & & & & & \\
\hline \multirow[b]{2}{*}{ Model } & \multicolumn{2}{|c|}{$\begin{array}{l}\text { Unstandardized } \\
\text { Coefficients }\end{array}$} & \multicolumn{3}{|c|}{ Standardized Coefficients } \\
\hline & B & Std. Error & Beta & $\mathrm{t}$ & Sig. \\
\hline 1 (Constant) & 18.703 & 5.107 & & 3.662 & .000 \\
\hline Disiplin & .272 & .087 & .299 & 3.132 & .002 \\
\hline Motivasi & .492 & .110 & .426 & 4.459 & .000 \\
\hline \multicolumn{6}{|c|}{ a. Dependent Variable: Kinerja } \\
\hline \multicolumn{6}{|c|}{ Sumber : Olahan SPSS 24} \\
\hline
\end{tabular}

Hasil regresi linear berganda $\mathrm{Y}=\mathrm{a}+\mathrm{b}_{1} \mathrm{X}_{1}+$ $\mathrm{b}_{2} \mathrm{X}_{2}$ yang telah ditemukan adalah $\mathrm{Y}=18,703+$ $0,272 \mathrm{X}_{1}+0,492 \mathrm{X}_{2}$

Hasil tersebut dapat disimpulkan bahwa:

a) Nilai constanta a sebesar 18,703 yang diartikan bahwa, jika variabel independen (Disiplin kerja, dan motivasi kerja) tidak ada atau $\mathrm{X}=0$ maka nilai kinerja karyawan saat ini sebesar 18,703.

b) Nilai constanta $b\left(b_{1} x_{1}\right)$ sebesar 0,272 diartikan bahwa, jika disiplin kerja ditingkatkan satusatuan maka akan di ikuti kenaikan kinerja karyawan sebesar 0,272.

c) Nilai constantab $\left(b_{2} x_{2}\right)$ sebesar 0,492 diartikan bahwa, jika motivasi kerja ditingkatkan satusatuan maka akan di ikuti kenaikan kinerja karyawan sebesar 0,492.

d) Signifikansi antara disiplin kerja terhadap kinerja karyawan adalah nilai Sig $0.002<$ 0,05 atau nilai $\mathrm{t}_{\text {hitung }} 3,132>\mathrm{t}_{\text {tabel }} 1,989$ maka $\mathrm{H}_{\mathrm{o}}$ ditolak dan $\mathrm{H}_{\mathrm{a}}$ di terima artinya terdapat pengaruh secara parsial antara disiplin kerja terhadap kinerja karyawan Departemen Sales Marketing Pada PT Perma Plasindo Jakarta.

e) Signifikansi antara motivasi kerja terhadap kinerja karyawan adalah nilai Sig $0.000<$ 0,05 atau nilai $\mathrm{t}_{\text {hitung }} 4,459>\mathrm{t}_{\text {tabel }} 1,989$ maka $\mathrm{H}_{\mathrm{o}}$ di tolak dan $\mathrm{H}_{\mathrm{a}}$ di terima artinya terdapat pengaruh motivasi kerja terhadap kinerja karyawan Departemen Sales Marketing Pada PT Perma Plasindo Jakarta.

Hasil pengujian koefisien korelasi secara simultan, seperti pada gambar di bawah ini : 


\begin{tabular}{|c|c|c|c|c|c|}
\hline \multicolumn{6}{|c|}{ Tabel 6. Hasil Koefisien Korelasi } \\
\hline \multicolumn{6}{|c|}{ Model Summary ${ }^{b}$} \\
\hline Model & $\mathbf{R}$ & R Square & $\begin{array}{l}\text { Adjusted } \\
\text { R Square }\end{array}$ & $\begin{array}{l}\text { Std. Error } \\
\text { of the Estimate }\end{array}$ & $\begin{array}{l}\text { Durbin- } \\
\text { Watson }\end{array}$ \\
\hline 1 & $.607^{\mathrm{a}}$ & .369 & .353 & 4.916 & 1.710 \\
\hline \multicolumn{6}{|c|}{$\begin{array}{l}\text { a. Predictors: (Constant), motivasi, disiplin } \\
\text { Dependent Variable: kinerja }\end{array}$} \\
\hline \multicolumn{6}{|c|}{ Sumber: Olahan SPSS 24} \\
\hline
\end{tabular}

Dari model summary di atas, menunjukkan bahwa, nilai korelasi $\mathrm{rx}_{1} \mathrm{x}_{2} \mathrm{y} 0,607$ hasil ini dapat disimpulkan bahwa kedua variabel disiplin kerja dan motivasi kerja memiliki tingkat hubungan kuat terhadap kinerja karyawan. Sedangkan nilai $r$ square 0,369 hasil ini dapat disimpulkan bahwa variabel disiplin kerja dan motivasi kerja memberikan kontribusi atau sumbangan sebesar $36,9 \%$ terhadap kinerja, dan sisanya $63,1 \%$ dipengaruhi oleh faktor lain.

Hasil uji hipotesis secara simultan menggunakan SPSS dapat penulis sajikan seperti pada tabel di bawah ini:

Tabel 7. Hasil Uji Hipotesis Secara Simultan (Uji F)

\begin{tabular}{|c|c|c|c|c|c|c|}
\hline \multicolumn{7}{|c|}{ ANOVA $^{a}$} \\
\hline \multicolumn{2}{|c|}{ Model } & $\begin{array}{l}\text { Sum of } \\
\text { Squares }\end{array}$ & df & $\begin{array}{l}\text { Mean } \\
\text { Square }\end{array}$ & $\mathrm{F}$ & Sig. \\
\hline 1 & Regression & 1144.268 & 2 & 572.134 & 23.670 & $.000^{\circ}$ \\
\hline & Residual & 1957.875 & 81 & 24.171 & & \\
\hline & Total & 3102.143 & 83 & & & \\
\hline
\end{tabular}

Dari Anova di atas menunjukkan bahwa, nilai $\mathrm{F}_{\text {hitung }} 23,670$ dan nilai $\mathrm{F}_{\text {hitung }} 23,670>\mathrm{F}_{\text {tabel }}$ 3.11 atau nilai Sig $0,000<0.05$, maka Ha di terima (signifikan) artinya terdapat pengaruh secara simultan antara disiplin kerja dan motivasi kerja terhadap kinerja karyawan Departemen Sales Marketing Pada PT Perma Plasindo Jakarta.

\section{Pembahasan}

\section{Pengaruh Disiplin Kerja Terhadap Kinerja}

Pengujian hipotesis hipotesis ke satu hipotesis menyatakan terdapat pengaruh secara parsial antara disiplin kerja terhadap kinerja karyawan Departemen Sales Marketing Pada PT Perma Plasindo Jakarta dengan nilai Sig 0.002 $<0,05$ atau nilai $\mathrm{t}_{\text {hitung }} 3,132>\mathrm{t}_{\text {tabel }} 1,989$. Koefisien korelasi antara variabel disiplin kerja $\left(\mathrm{x}_{1}\right)$ terhadap kinerja (Y) sebesar $\mathrm{rx}_{1} \mathrm{y}$ 0,463 hasil tersebut dapat disimpulkan bahwa variabel disiplin kerja memiliki tingkat hubungan sedang terhadap kinerja karyawan. Sedangkan hasil koefisien determinasi $\mathrm{r}$ square $\left(\mathrm{r}^{2}\right)$ dengan mengkuadratkan nilai $\mathrm{rx}_{1} \mathrm{y} \quad 0,463=0,214$ hasil ini dapat disimpulkan bahwa variabel disiplin kerja memberikan kontribusi atau sumbangan sebesar $21,4 \%$ terhadap kinerja, dan sisanya $78,6 \%$ dipengaruhi oleh faktor lain.

\section{Pengaruh Motivasi Terhadap Kinerja}

Pengujian hipotesis kedua juga menyatakan terdapat pengaruh motivasi kerja terhadap kinerja karyawan Departemen Sales Marketing Pada PT Perma Plasindo Jakarta dengan nilai Sig $0.000<0,05$ atau nilai $\mathrm{t}_{\text {hitung }} 4,459>\mathrm{t}_{\text {tabel }} 1,989$. Koefisien korelasi antara variabel motivasi $\left(\mathrm{x}_{2}\right)$ terhadap kinerja (Y) sebesar $\mathrm{rx}_{2} \mathrm{y} \quad 0,541$ hasil tersebut dapat disimpulkan bahwa variabel motivasi kerja memiliki tingkat hubungan sedang terhadap kinerja karyawan. Sedangkan hasil koefisien determinasi $r$ square $\left(\mathrm{r}^{2}\right)$ dengan mengkuadratkan nilai $\mathrm{rx}_{1} \mathrm{y} \quad 0,541=0,292$ hasil ini dapat disimpulkan bahwa variabel motivasi kerja memberikan kontribusi atau sumbangan sebesar $29,2 \%$ terhadap kinerja, dan sisanya 70,8\% dipengaruhi oleh faktor lain.

\section{Pengaruh Disiplin Kerja dan \\ Motivasi Terhadap Kinerja}

Pengujian hipotesis secara simultan dalam penelitian ini, terdapat pengaruh secara simultan antara disiplin kerja, dan motivasi kerja terhadap kinerja karyawan Departemen Sales Marketing Pada PT Perma Plasindo Jakarta, hal ini ditunjukkan dengan nilai $\mathrm{F}_{\text {hitung }} 23,670>\mathrm{F}_{\text {tabel }}$ 3.11 atau nilai Sig $0,000<0.05$. Pengaruh secara simultan antara disiplin kerja dan motivasi kerja terhadap kinerja karyawan juga ditunjukkan dengan hasil regresi linear berganda $\mathrm{Y}=18,703+$ $0,272 \mathrm{X}_{1}+0,492 \mathrm{X}_{2}$. Nilai constanta a sebesar 18,703 yang diartikan bahwa, jika variabel independen (Disiplin kerja, dan motivasi kerja) tidak ada atau $\mathrm{X}=0$ maka nilai kinerja karyawan saat ini bernilai 18,703. Nilai constanta $b\left(b_{1} x_{1}\right)$ sebesar 0,272 diartikan bahwa, jika disiplin kerja ditingkatkan satu-satuan maka akan diikuti kenaikan kinerja 
karyawan sebesar 0,272 . Nilai constanta $\mathrm{b}\left(\mathrm{b}_{2} \mathrm{x}_{2}\right)$ sebesar 0,492 diartikan bahwa, jika motivasi kerja ditingkatkan satu-satuan maka akan diikuti kenaikan kinerja karyawan sebesar 0,492. Nilai korelasi $\mathrm{rx}_{1} \mathrm{x}_{2} \mathrm{y}$ 0,607 hasil ini dapat disimpulkan bahwa variabel disiplin kerja dan motivasi kerja memiliki tingkat hubungan kuat terhadap kinerja karyawan. Sedangkan kontribusi variabel disiplin kerja dan motivasi kerja memberikan kontribusi atau sumbangan sebesar 36,9\% terhadap kinerja, dan sisanya $63,1 \%$ dipengaruhi oleh faktor lain.

\section{SIMPULAN}

Hasil penelitian yang telah dilakukan dalam menjawab rumusan masalah dalam penelitian, maka hasil kesimpulan dari pengujian analisa statistik dengan bantuan software SPSS 24 dapat disajikan seperti di bawah ini :

Pengaruh disiplin kerja terhadap kinerja karyawan menunjukkan bahwa, secara parsial menyatakan terdapat pengaruh secara parsial antara disiplin kerja terhadap kinerja karyawan dengan nilai Sig $0.002<0,05$ atau nilai $\mathrm{t}_{\text {hitung }} 3,132$ $>t_{\text {tabel }} 1,989$.

Pengaruh motivasi kerja terhadap kinerja karyawan menunjukkan bahwa, secara parsial terdapat pengaruh motivasi kerja terhadap kinerja karyawan dengan nilai Sig $0.000<0,05$ atau nilai $\mathrm{t}_{\text {hitung }} 4,459>\mathrm{t}_{\text {tabel }} 1,989$.

Pengaruh secara simultan antara disiplin kerja dan motivasi kerja terhadap kinerja karyawan Departemen Sales Marketing Pada PT Perma Plasindo Jakarta, hal ini ditunjukkan dengan nilai $\mathrm{F}_{\text {hitung }} 23,670>\mathrm{F}_{\text {tabel }} 3.11$ atau nilai Sig $0,000<0.05$.

\section{DAFTAR PUSTAKA}

Abdullah M. M. (2014). Manajemen dan Evaluasi Kinerja Karyawan. Yogyakarta: Aswaja Pressindo.

Arifin. M dan Barnawi. (2012). Manajemen Sarana dan Prasarana Sekolah. Yogyakarta: ARRuzz Media.

Bangun, W. (2012). Manajemen Sumber Daya Manusia. Bandung: Erlangga.

Ghozali, I. (2013). Analisis Multivariate. Semarang: Universtitas Dipenegoro.
Handoko, T H. (2014). Manajemen Personalia \& Sumber Daya Manusia, Cetakan Ke 21 Edisi Ke 2. Yogyakarta: BPFE.

Hasibuan, S. P M. (2013). Manajemen Sumber Daya Manusia. Jakarta: Bumi Aksara.

Mangkunegara, P. A. (2013). Manajemen Sumber Daya Manusia Perusahaan. Bandung: Remaja Rosdakarya.

Nitisemito, A. S. (2008). Manajemen Personalia. Jakarta: Sasmita Bross.

Noelaka, A. (2014). Metode Penelitian Dan Statistik. Jakarta: Remaja Rosdakarya.

Sedarmayanti. (2013). Manajemen Sumber Daya Manusia Cetakan Ke 6. Bandung: Refika Aditama.

Siagian, P. S. (2012). Manajemen Sumber Daya Manusia. Jakarta: Bumi Aksara.

Simamora, H. (2014). Manajemen Sumber Daya Manusia. Yogyakarta: YKPN.

Siregar, S. (2014). Satatistik Parametrik Untuk Penelitian Kuantitatif. Jakarta: Bumi Aksara.

Subhekti, A. dan Muhammad, J. (2012). Pengantar Manajemen Sumber Daya Manusia, Cetakan Pertama. Jakarta: Prestasi Pustakarya.

Sugiyono. (2010). Metode Penelitian Bisnis. Cetakan ke 15. Bandung: Alfabet.

Sujarweni, V W. (2014). Metodologi Penelitian. Yogyakarta: Pustaka Baru Press.

Sutrisno, E. (2015). Manajemen Personalia Dan Manajemen Sumber Daya Manusia. Jakarta: Prenada Media Group.

Terry, G. dan Leslie W.R.Dasar-Dasar Manajemen, Cetakan kesebelas. Jakarta: Bumi Aksara.

Winardi. (2011). Motivasi Dan Pemotivasian Dalam Manajemen. Jakarta: Raja Grafinfo Persada.

Wirawan. (2012). Evaluasi Kinerja Sumber Daya Manusia: Teori. Aplikasi dan Penelitian. Jakarta: Salemba Empat.

Yuniarsih, T. \& Suwatno. (2013). Manajemen Sumber Daya Manusia Teori. Aplikasi dan Isu Penelitian. Cetakan Ke 4. Bandung: Alfabeta. 